\title{
Treatment time of ultrasound therapy interferes with the organization of collagen fibers in rat tendons
}

\author{
Thiago S. Farcic ${ }^{1,2,3}$, Cristiano S. Baldan ${ }^{1,2,4}$, Carla G. Cattapan ${ }^{1}$, \\ Nivaldo A. Parizotto ${ }^{5}$, Silvia M. A. João ${ }^{1}$, Raquel A. Casarotto ${ }^{1}$
}

\begin{abstract}
Background: The application time of therapeutic ultrasound is an infrequently studied dosimetric variable that affects tissue repair. Objectives: The aim of this study was to evaluate the effects of different treatment times of therapeutic ultrasound (US) on the organization of collagen fibers in the tendons of rats. Method: Forty Wistar rats were selected $(300 \pm 45 \mathrm{~g})$, and the rats were divided into five groups ( $\mathrm{n}=8$ for each group): Control, without tenotomy or any treatment; tenotomy group, with tenotomy and without treatment; US groups (US1, US2, and US3), subjected to tenotomy and treated with US for one, two, or three minutes per area of the transducer, respectively. The animals were sacrificed on the 12th post-operative day, and the tendons were surgically removed for analyses of the collagen fiber organization by means of birefringence analysis. Results: The collagen fibers exhibited better aggregation and organization in the US3 group compared with the tenotomy group $(p<0.05)$. Conclusions: The findings suggest that US applied for three minutes per treated area improves the organization of collagen fibers during rat tendon repair.
\end{abstract}

Keywords: therapeutic ultrasound; Achilles tendon; physical therapy; collagen; wound healing.

\section{HOW TO CITE THIS ARTICLE}

Farcic TS, Baldan CS, Cattapan CG, Parizotto NA, João SMA, Casarotto RA. Treatment time of ultrasound therapy interferes with the organization of collagen fibers in rat tendons. Braz J Phys Ther. 2013 May-June; 17(3):263-271. http://dx.doi.org/10.1590/ S1413-35552012005000090

\section{Introduction}

The healing process of tendon injuries can take months, although the use of electrotherapeutic resources may help accelerate recovery and prevent functional complications that might otherwise delay the rehabilitation process ${ }^{1}$. The high incidence of these injuries justifies more studies to improve tendon repair by reducing recovery time and the time to return to functional activities ${ }^{2}$. Researchers have studied non-pharmacological treatment modalities to accelerate tissue repair, including therapeutic ultrasound (US) and low-intensity laser therapy ${ }^{1,3-6}$.

US therapy has been used to treat musculoskeletal injuries, particularly in tissues with a high percentage of collagen fibers ${ }^{4,7-12}$. Harvey et al. ${ }^{13}$ described the following physiological responses involved in soft tissue repair when the tissue is submitted to US: acceleration of inflammatory responses by promoting the release of histamines, macrophages, and monocytes; increases in cellular metabolism and collagen synthesis; and decreases in edema and pain $^{14-17}$.
Studies regarding the efficacy of US therapy demonstrate that there are no precise guidelines for its parameters, particularly with respect to the doseresponse of the treatments ${ }^{18-21}$. Most professionals justify their use of US therapy with their clinical experience ${ }^{18,22-24}$.

The dose-response of therapeutic US is influenced by many variables, including frequencies, intensities, irradiation times, application modes, type and coupling techniques, and early post-injury interventions ${ }^{25-28}$. A systematic review on the effectiveness of US therapy in musculoskeletal injuries found no evidence of its effectiveness. Warden and McMeeken ${ }^{19}$ concluded that US is often used by physical therapists in sport rehabilitation, but there is no evidence to support the dosimetry used. Robertson ${ }^{18}$ noted that a therapeutic window ranging from 0.16 to $0.5 \mathrm{~W} / \mathrm{cm}^{2}$ in pulsed mode, suggested by previous studies, has proven to be illusory; the variables analyzed in the few studies available, such as frequencies, duration of treatments, types and depths of the injury, the effective radiation

\footnotetext{
${ }^{1}$ Physical Therapy Department, Occupational Therapy and Fonoaudiology, Universidade de São Paulo (USP), São Paulo, SP, Brazil

${ }^{2}$ Physical Therapy Course, Health Science Institute, Universidade Paulista (UNIP), São Paulo, SP, Brazil

${ }^{3}$ Physical Therapy Course, Mario Schenberg College, São Paulo, SP, Brazil

${ }^{4}$ Physical Therapy Course, Health College, Universidade Metodista de São Paulo (UMESP), São Paulo, SP, Brazil

${ }^{5}$ Physical Therapy Department, Universidade Federal de São Carlos (UFSCar), São Carlos, SP, Brazil

Received: 07/06/2012 Revised: 10/23/2012 Accepted: 11/26/2012
} 
area, and the size of the treated areas, make comparisons impossible. These considerations are corroborated by the findings of Speed ${ }^{29}$, who supported the exclusion of US therapy due to a lack of evidence.

The US application time influences the amount of energy applied to the tissue, which is calculated by the following formula: Energy (Joules) $=$ Power (Watts) * Time (Seconds) ${ }^{30}$. The treatment time is an infrequently studied variable in US therapy. The relationship between the time of application and the treated area has been described by Oakley ${ }^{31}$. Oakley ${ }^{31}$ proposed that each area of $1 \frac{1}{2}$ times the size of the transducer should be treated for one to two minutes. Furthermore, for each area adjacent to the transducer, an additional one to $1 \frac{1}{2}$ minutes of treatment was advised, although these relationships were not grounded or justified. Hoogland ${ }^{32}$ recommended a maximum treatment time of 15 minutes and at least 1 minute for each treated area. Conversely, Olsson et al. ${ }^{24}$ concluded that there was no definitive recommended treatment time for US application.

Experimental studies on tendon repair using ultrasound follow the recommendation of 1-2 minutes per transducer treated $d^{6,33,34}$. The rationale for this treatment is based on previous studies using the same application time or following the recommendations of Oakley ${ }^{31}$ and Hoogland ${ }^{32}$, who proposed this time empirically. There are no studies in cell culture, animal tendons or human tendons concerning different US application times. Thus, there is no evidence to justify the choice of this dosimetric parameter for tendon healing. The effects of irradiation time as a function of frequency and depth of penetration has been evaluated in human muscle tissue by Draper et al. ${ }^{25}$. There is a good basis for US application in individuals with little adipose tissue overlying the muscle. The effect of treatment time on tendon healing needs to be studied to improve the efficiency of ultrasound application.

Therefore, the aim of this study was to evaluate the effects of different US therapy treatment times on the organization of collagen fibers in rat tendons.

\section{Method}

This study was approved by the ethical research board of the Faculty of Medicine of the Universidade de São Paulo (USP), São Paulo, SP, Brazil (nº 065/11 04/13/2011). The surgical procedures followed the ethical guidelines for animal experiments of the Council for the International Organization of Medical Sciences, the standards of the Brazilian Society of
Laboratory Animal Sciences, and the current national legislation on procedures for the scientific use of animals in research (Federal Law 11,794, October 9th, 2008).

\section{Animals}

Forty male Wistar rats were used in this study (weight: $300 \pm 45 \mathrm{~g}$, age: 90 days). The animals were kept in a controlled environment at a temperature of $25^{\circ} \mathrm{C}$ and a light/dark cycle of 12 hours and were provided with a balanced diet for rodents and water ad libitum. The rats were randomly divided into five groups of eight rats. The number of animals needed to achieve statistical significance was based on previous studies $^{35,36}$.

The animals were divided into the following groups: control group, without surgery and US therapy; tenotomy group, with tenotomy of the Achilles tendon and without US therapy; US1 group, with tenotomy of the Achilles tendon and US treatment for one minute per transducer area, totaling two minutes of treatment; US2 group, with tenotomy of the Achilles tendon and US treatment for two minutes per area of the transducer, totaling four minutes of treatment; and the US3 group, with tenotomy of the Achilles tendons and US treatment for three minutes per area of the transducer, totaling six minutes of treatment.

\section{Experimental model}

The model for the total tenotomy of the middle portion of the Achilles tendon (transverse incision of the dissected tendon) was based upon experiments performed by Cunha et al. ${ }^{14}$, Reddy et al. ${ }^{37}$, Koeke et al. ${ }^{38}$, and Carrinho et al. ${ }^{39}$.

\section{Surgical technique}

The animals were weighed and anesthetized with veterinarian tiletamine hydrochloride and zolazepam hydrochloride (Zoletil 50 - VIRBAC ${ }^{\circledR}$ ) at a dose of $25 \mathrm{mg} / \mathrm{kg}$ of body mass via intraperitoneal injections ${ }^{40}$. The posterior areas of the right tibia, corresponding to the location of the Achilles tendon, were epilated. Afterwards, asepsis was achieved with alcohol $70 \%$, and the skin and the panniculus carnosus were cut longitudinally over the site corresponding to the middle third of the Achilles tendon with a scalpel blade, exposing the tendon to obtain a cross-section ${ }^{22}$ (Figure 1). After sectioning the tendon, the skin incision was completely sutured in the central area using 4.0 nylon thread (Figure 2). Post-operatively, the animals received a single intramuscular dose 


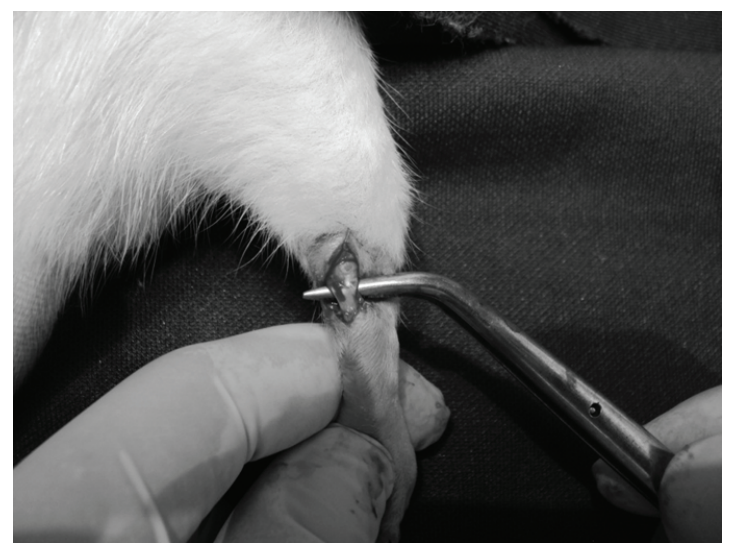

Figure 1. Longitudinal incision and exposure of the Achilles tendon on the posterior of the rat's hind limb.

of Ceftriaxone in the contralateral hind limb for antibiotic prophylaxis and were returned to sterilized cages without immobilization ${ }^{14,37-39,41}$. The right Achilles tendon was submitted to US in the US1, US2 and US3 groups.

\section{Treatment protocols}

The Sonacel BIOSET ${ }^{\circledR}$ US emitter was used. The design of its transducer, which has an area of $0.5 \mathrm{~cm}^{2}$, was modified to fit the posterior portion of the rats' hind limbs and the size of the lesions. The equipment was calibrated with an acoustic scale (GT210 Glutymax ${ }^{\circledR}$ ) and an oscilloscope (Intermetro ${ }^{\circledR}$ ).

The animals were submitted to the first application of US therapy 24 hours after the surgery. The ultrasonic irradiation employed the following parameters: $1 \mathrm{MHz}$ frequency, pulsed mode with $20 \%$ of the duty cycle $(2 \mathrm{~ms}$ emission $/ 8 \mathrm{~ms}$ interval), $100 \mathrm{~Hz}$ repetition frequency, $0.5 \mathrm{~W} / \mathrm{cm}^{2}$ of intensity (spatial average time average - SATA), and $0.5 \mathrm{~cm}^{2}$ ERA and was performed once per day. The treated area was $1 \mathrm{~cm}^{2}$ in size. The animals were sacrificed after the 10th treatment session on the 12th post-operative day. The irradiations occurred consecutively at one day intervals after the fifth treatment day ${ }^{3,4,18,38,42}$.

During the US applications, the transducer was placed perpendicular to the treated area using movement techniques. Water-soluble gel was used as a coupling agent to better conduct the waves and facilitate movement over the rat's skin ${ }^{27,43}$. The animals were also stabilized with a standard retainer (Figure 3$)^{14,38}$.

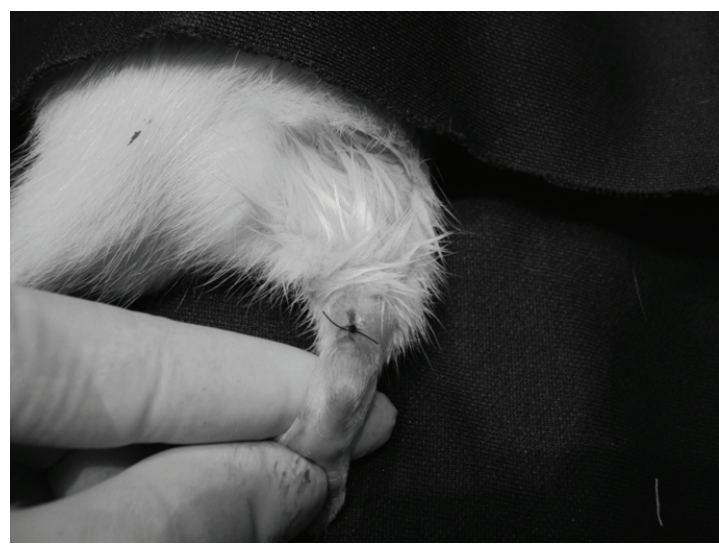

Figure 2. Surgical incision sutures with 4.0 nylon surgical thread.

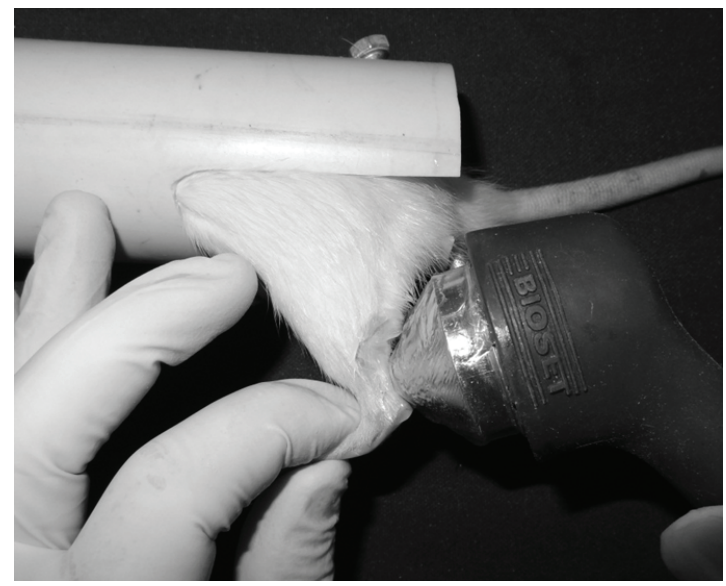

Figure 3. Constraint and irradiation of the Achilles tendon on the posterior of the rat's hind limb

\section{Preparation and analysis of the histological slides}

The animals were sacrificed using a $\mathrm{CO}_{2}$ chamber, and the damaged tendon areas were surgically removed. For the quantitative assessment of tendon repairs, the removed tendons were placed in a $10 \%$ formalin solution for 24 hours and were subsequently dehydrated with four alcohol baths of one hour each at dilutions of 50\%, 70\%, 80\%, and $100 \%$. Subsequently, the samples were washed in xylene for one hour and embedded in paraffin at $58^{\circ} \mathrm{C}$. The blocks were longitudinally cut into serial sections using a microtome (LAICA ${ }^{\circledR}$ ) with a standard thickness of $7 \mu \mathrm{m}$. The sections were mounted on glass slides without staining and identified by a blinded evaluator.

The uneven penetration of light through an object is a measure of birefringence. This measure assesses the density and organization of the analyzed material and is used to evaluate the organization and structure of the collagen fibers. The purpose of this procedure 
was to analyze the organization, the aggregation states, and the alignment of the tendon collagen fibers by measuring their birefringence ${ }^{14,20,39}$. For the birefringence analyses, the slides for each group were immersed in distilled water (refractive index $\eta=1.333$ ) for 30 minutes. The optical retard (OR) was measured using a polarized light microscope $\left(\right.$ LEICA $\left.^{\circledR}\right)$ with a 10X/0.22 objective, pol. 0.9 condenser, Senarmont $\lambda / 4$ compensator, and monochromatic light $(\lambda=546$ $\mathrm{nm})$ obtained by an interference filter $\left(\right.$ LEICA $\left.^{\circledR}\right)$ of the LAMAV (Vitreous materials laboratory, Department of material Engineering of UFSCar). These types of analyses have been used to quantitatively measure the degrees of organization of the collagen fibers in several studies ${ }^{14,20,38}$. The resulting measures, in degrees, were converted into nanometers $(\mathrm{nm})$ by multiplying the values by 3.03 . The total birefringence of the collagen fibers was measured after soaking the tendons in distilled water. To perform the measurements along the axis of the tendon, the longitudinal axis of the collagen fibers was oriented $45^{\circ}$ from the direction of the propagation of the transmission light. In this position, the collagen fibers have the highest OR. Measurements were taken at five different points on the central areas of the tendons, which corresponded to the areas of the injuries ${ }^{14,20,38,39}$. The birefringence data were collected by two previously trained, independent, and blinded assessors.

\section{Statistical analyses}

The data distributions were tested using the Kolmogorov-Smirnov test. Subsequently, the data were analyzed using the Kruskal-Wallis test, followed by Dunn's post-hoc test to investigate differences between the groups with a significance level of $\alpha<0.05$.

\section{Results}

Kruskall-Wallis tests revealed statistically significant differences among the groups with respect to the OR of the five different areas of each injury region $(p<0.0001)$. Dunn's multiple post-hoc tests demonstrated statistically significant differences when comparing the OR data between the following groups: US1xUS2, US1xUS3, US1xC, US2xC, US3xT, and CxT (Figure 4).

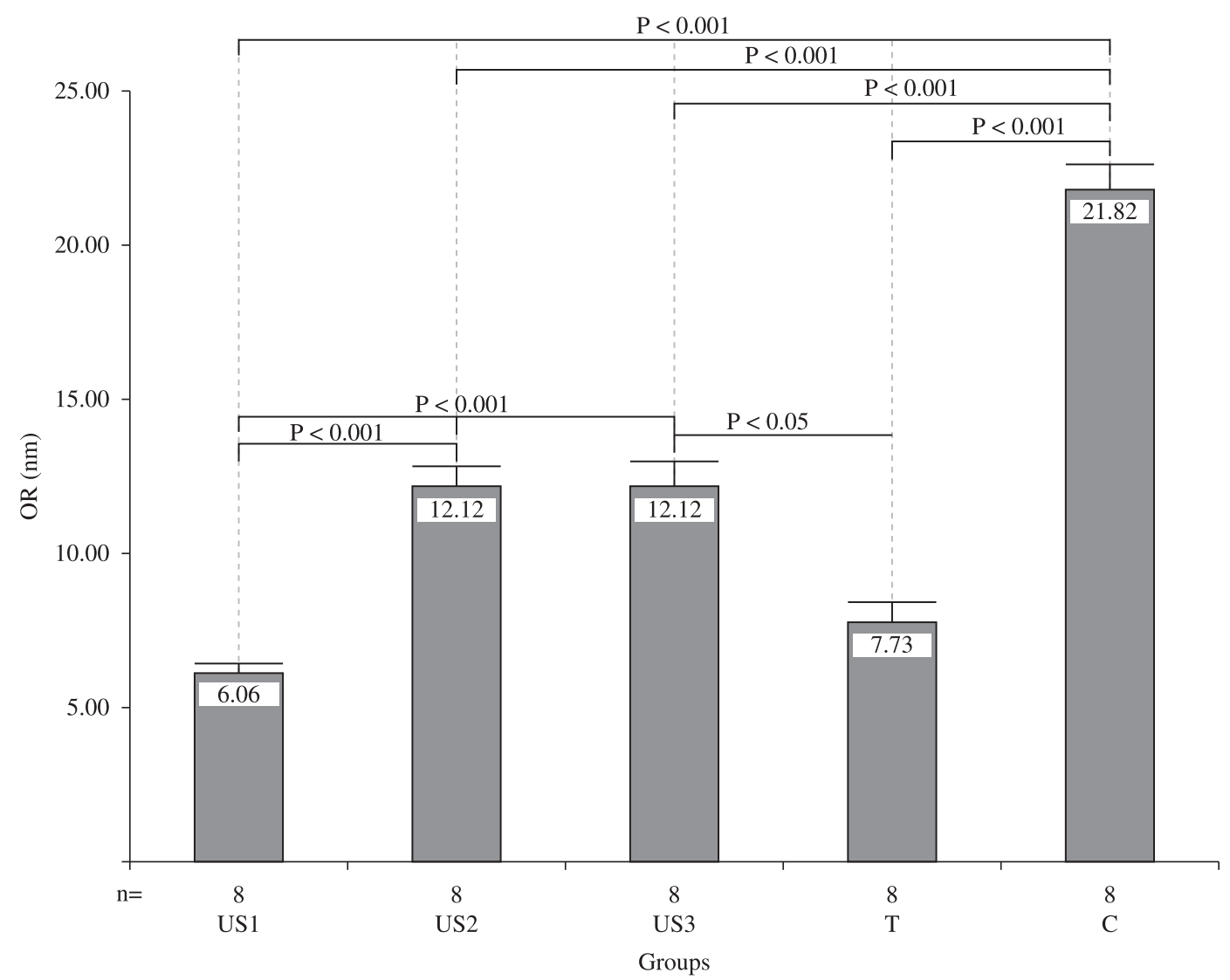

Figure 4. Median and standard errors of the optical delay values for the experimental groups. 
Qualitative histological analyses using polarized light microscopy allow the definition of normality standards regarding the organization of the collagen fibers (Figure 5). When comparing the images in Figure 5, it is possible to observe that the animals of the US3 group demonstrated better organization of the collagen fibers when compared to the other treated groups (US1 and US2). It is also possible to observe that the collagen fibers of the animals in the US1 and tenotomy groups were not organized.

\section{Discussion}

The aim of this study was to evaluate the effects of different US application times on tendon repair in tenotomized rats, and the results suggested that application times of less than three minutes were insufficient to promote adequate organization of the collagen fibers. The literature also does not provide clear definitions regarding US therapy treatment times. US doses are the most frequently studied
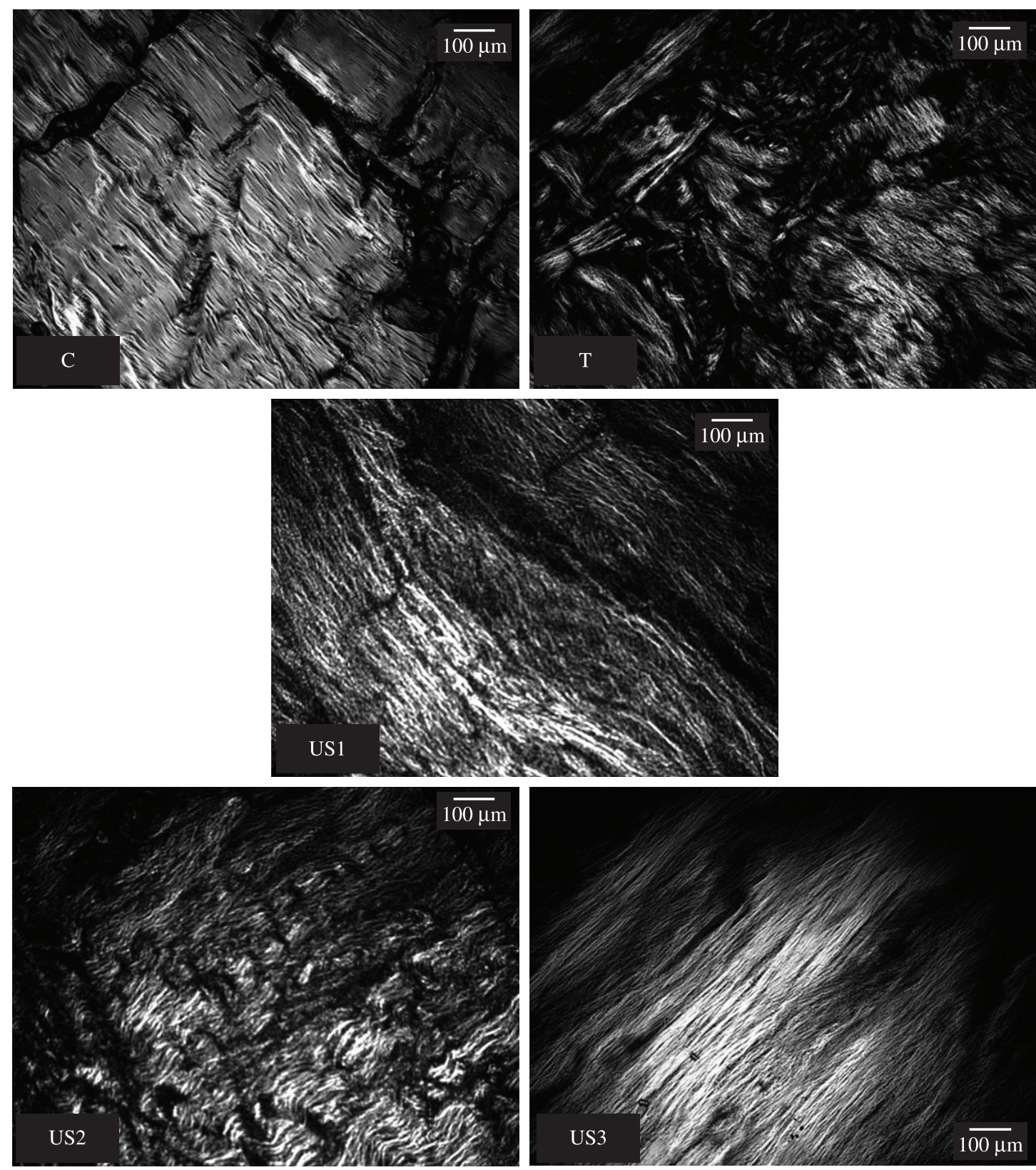

Figure 5. Images related to the qualitative observations of the birefringence analyses of the tenotomized rat tendons. Specimens were positioned with the longitudinal axes of the collagen fibers at 45 degrees. In the US1, US2 and tenotomy (T) images, deficiencies in the organization of the collagen fibers can be observed. The US3 image demonstrates better organization of the collagen fibers, similar to that of the control group (C). 
variables $^{15,30}$, and there is evidence that lower doses are more effective for tissue repair ${ }^{44}$.

The dose standards employed in the present study were those most often used in US therapy studies, and the treatment times were the studied variables. The intensity $\left(0.5 \mathrm{~W} / \mathrm{cm}^{2}\right)$ was based upon the research of Carvalho et al. ${ }^{4}$, Cunha et al. ${ }^{14}$, Reddy et al. ${ }^{37}$, Koeke et al. ${ }^{38}$, and Silva et al. ${ }^{45}$. The form of ultrasonic pulsed emission was chosen based on research conducted by Carvalho et al. ${ }^{4}$, Cunha et al. ${ }^{14}$, Frasson et al. ${ }^{17}$, Blume et al. ${ }^{22}$, Koeke at al..$^{38}$, and Belanger et $a .^{46}$. The frequency of the equipment was justified by the experiments by Carvalho et al. ${ }^{4}$, Piedade et al. ${ }^{11}$, Cunha et al. ${ }^{14}$, and Koeke et al..$^{38}$.

The treatment duration is known to depend upon the area of the injury. Oakley ${ }^{31}$ recommended that the treatment time be related to the treated area, with one or two minutes for each area that is $1 \frac{1}{2}$ times the size of the transducer. According to Oakley ${ }^{31}$, subsequent treatment times can be increased from 1 to $1 \frac{1}{2}$ minutes. This subsequent treatment time is based upon empirical studies or clinical observations. There are no clinical or experimental studies that support these findings, and this lack of information concerning treatment should be considered an issue for further study. The results of the present study do not corroborate the results of Oakley ${ }^{31}$ regarding the application times needed to promote better alignment of collagen fibers in rat tendons.

The application time is an important variable to be considered in US therapy dosimetry and determines the amount of energy applied to the treated tissue. Alexander et al. ${ }^{30}$, in a systematic review of the use of US in various shoulder pathologies, noted that studies that employed the average energy of $4.2 \mathrm{~J}$ per treatment session were clinically effective, whereas those that applied an average of $2.019 \mathrm{~J}$ were not successful. The duration of application may have influenced these data.

The components of the extracellular matrix of the connective tissues present in tendons, particularly the collagen fibers, exhibit viscoelastic properties that depend on the amount of time the tissue is exposed to deformations or strains to keep their morphofunctional characteristics ${ }^{47}$. There is a direct relationship between the alignment of collagen fibers of the extracellular matrix and the biomechanical properties of tendon: when the collagen fibers exhibit better organization, the flexibility and strength of these tendons also improve ${ }^{48}$.

Thus, three minutes of US application could have sufficient biomechanical effects, compression and/or tension to promote the mechanisms of cellular and matrix extracellular signaling for the realignment of the collagen fibers ${ }^{49}$.

In this study, the OR in the tendon scar tissues of rats demonstrated statistically significant differences when $18 \mathrm{~J}$ of energy (group US3) was applied to the affected area. However, when other magnitudes of energy, namely, $6 \mathrm{~J}$ (US1 group) or $12 \mathrm{~J}$ (group US2), were deposited on the treated area, no differences were observed regarding the OR between the experimental and control groups.

The most commonly employed application time is five minutes, and the US is generally applied to an area twice the size of the transducer, resulting in an application time of 2.5 minutes per treated area $^{6,38}$. The size of the treated area is a variable that has not been described in studies related to US therapy and tendon repair. Wood et al. ${ }^{6}$, Cunha et al. ${ }^{14}$, and Koeke et al. ${ }^{38}$ applied US therapy to an area of $1 \mathrm{~cm}^{2}$, but these data were not described in the articles and were instead personally provided by the authors. The present study demonstrated that longer application times are needed to promote better alignment of the collagen fibers. One hypothesis to explain the differences between the results of this and previous studies is that the control of the treated areas may not have been accurately measured, making it impossible to compare findings. This variable must be considered when designing the experiment so that comparisons between studies can be made.

The relevance of studying and developing techniques to treat tendon injuries relates to the long recovery times and the resulting functional disabilities of tendon injuries, which may take weeks or even months to fully recover ${ }^{1,3,50}$. The tensile strength of the tendons is promoted by the alignment of their collagen fibers and by the types and amount of fibers. Thus, this study used an experimental model already defined in the literature, described by Enwemeka and Reddy ${ }^{1}$ and reproduced by other authors ${ }^{14,37-39,41}$, that exhibits easy reproducibility, lower costs, and high levels of reliability.

The levels of collagen fiber organization in the injured area are measured according to the OR in the polarized light microscope, which provides quantitative data. The brightness of the birefringence image reveals the level of aggregation of the collagen fibers ${ }^{14}$. During the process of tissue repair, the OR values tend to decrease ${ }^{39}$, corroborating the results of the present study, in which the US1 group demonstrated the lowest OR values, followed by the tenotomy, US2, US3, and control groups. 
The findings of the present study suggest that three minutes of application per area of the US transducer results in positive effects on the collagen fiber organization in rat tendons during the tissue repair process, producing significant changes in the collagen optical retards. Shorter application times produced no significant changes in the optical delays when compared to the tenotomy group.

The transposition of the experimental findings to the clinical application of therapeutic ultrasound on tendon healing should be evaluated with respect to the difference between the application times of 2 and 3 minutes. Further studies are needed to assess the difference between these treatment times with regard to human healing.

\section{References}

1. Enwemeka CS, Reddy K. The biological effects of laser therapy and other physical modalities on connective tissue repair processes. J Laser Ther. 2000;12:22-30. http:// dx.doi.org/10.5978/islsm.12.22

2. Tumilty S. Achilles tendon ruptures: rising incidence in New Zealand follows international trends. Phys Ther Rev 2007;2(1):59-65. http://dx.doi. org/10.1179/108331907X174998

3. Saini NS, Roy KS, Bansal PS, Singh B, Simran PS. A preliminary study on the effect of ultrasound therapy on the healing of surgically severed achilles tendons in five dogs. J Vet Med A Physiol Pathol Clin Med. 2002;49(6):321-8. PMid:12227476. http://dx.doi. org/10.1046/j.1439-0442.2002.00441.x

4. Carvalho PT, Silva IS, Reis FA, Belchior AC, Aydos RD, Facco GG, et al. Histological study of tendon healing in malnourished Wistar rats treated with ultrasound therapy. Acta Cir Bras. 2006;21(Suppl 4):13-7. http://dx.doi. org/10.1590/S0102-86502006001000004

5. Neves MA, Pinfildi CE, Wood VT, Gobbato RC, Da Silva FM, Parizotto NA, et al. Different Power Settings of LLLT on the Repair of the Calcaneal Tendon. Photomed Laser Surg. 2011;29(10):663-8. PMid:21668375. http://dx.doi. org/10.1089/pho.2010.2919

6. Wood VT, Pinfildi CE, Neves MA, Parizoto NA, Hochman B, Ferreira LM. Collagen changes and realignment induced by low-level laser therapy and lowintensity ultrasound in the calcaneal tendon. Lasers Surg Med. 2010;42(6):559-65. PMid:20662033. http://dx.doi. org/10.1002/lsm.20932

7. Johns LD. Nonthermal effects of therapeutic ultrasound: the frequency resonance hypothesis. J Athl Train. 2002;37(3):293-9. PMid:16558674 PMCid:164359.

8. Chipchase LS, Trinkle D. Therapeutic ultrasound: clinician usage and perception of efficacy. Hong Kong Physiother J. 2003;21(1):5-14. http://dx.doi.org/10.1016/ S1013-7025(09)70034-X

9. Larsen A, Kristensen G, Thorlacius-Ussing O, Oxlund $\mathrm{H}$. The influence of ultrasound on the mechanical properties of healing tendons in rabbits. Acta Orthop. 2005;76(2):225-30. PMid:16097548. http:// dx.doi.org/10.1080/00016470510030616

10. Wong RA, Schumann B, Townsend R, Phelps CA. A survey of therapeutic ultrasound use by physical therapists who are orthopaedic certified specialists. Phys Ther. 2007;87(8):986-94. PMid:17553923. http://dx.doi. org/10.2522/ptj.20050392

11. Piedade MC, Galhardo MS, Battlehner CN, Ferreira MA, Caldini EG, De Toledo OM. Effect of ultrasound therapy on the repair of gastrocnemius muscle injury in rats. Ultrasonics. 2008;48(5):403-11. PMid:18384832. http:// dx.doi.org/10.1016/j.ultras.2008.01.009

12. Romano CV, Barbieri CH, Mazzer N, Volpon JB, Shimano AC, Roncaglia FB. O ultra-som terapêutico não aumentou as propriedades mecânicas de tendões flexores após reparo. Acta Ortop Bras. 2010;18(1):10-4. http://dx.doi. org/10.1590/S1413-78522010000100001

13. Harvey W, Dyson M, Pond JB, Grahame $R$. The stimulation of protein synthesis in human fibroblasts by therapeutic ultrasound. Rheumatol Rehabil. 1975;14(4):237. PMid:1198016. http://dx.doi. org/10.1093/rheumatology/14.4.237

14. Cunha A, Parizotto NA, Vidal BC. The effect of therapeutic ultrasound on repair of the achilles tendon (tendo calcaneus) of the rat. Ultrasound $\mathrm{Med}$ Biol. 2001;27(12):1691-6. http://dx.doi.org/10.1016/ S0301-5629(01)00477-X

15. Ng CO, Ng GY, See EK, Leung MC. Therapeutic ultrasound improves strength of achilles tendon repair in rats. Ultrasound Med Biol. 2003;29(10):1501-6. http:// dx.doi.org/10.1016/S0301-5629(03)01018-4

16. Monte-Raso VV, Barbieri CH, Mazzer N, Fazan VPS. Os efeitos do ultra-som terapeutico nas lesões por esmagamento do nervo ciatico de ratos: analise funcional da marcha. Rev Bras Fisioter. 2006;10(1):113-9. http:// dx.doi.org/10.1590/S1413-35552006000100015

17. Frasson NF, Taciro C, Parizotto NA. Análise nanoestrutural da ação do ultra-som terapêutico sobre o processo de regeneração do tendão de ratos. Fisioter Pesqui. 2009;16(3):198-204. http://dx.doi.org/10.1590/ S1809-29502009000300002

18. Robertson VJ. Dosage and treatment response in randomized clinical trials of therapeutic ultrasound. Phys Ther Sport. 2002;3(3):124-33.

19. Warden SJ, McMeeken JM. Ultrasound usage and dosage in sports physiotherapy. Ultrasound Med Biol. 2002;28(8):1075-80. http://dx.doi.org/10.1016/ S0301-5629(02)00552-5

20. Vidal BC. Image analysis of tendon helical superstructure using interference and polarized light microscopy. Micron. 2003;34(8):423-32. http://dx.doi.org/10.1016/ S0968-4328(03)00039-8

21. Artilheiro PP, Oliveira EN, Viscardi CS, Martins MD, Bussadori SK, Fernandes KPS, et al. Efeitos do ultra-som terapêutico contínuo sobre a proliferação e viabilidade de células musculares C2C12. Fisioter Pesqui. 2010;17(2):167-72. 
22. Blume K, Matsuo E, Lopes MS, Lopes LG. Dosimetria proposta para o tratamento por ultra-som: uma revisão de literatura. Fisioter Mov. 2005;18(3):55-64.

23. Franco AD, Pereira LE, Groschitz M, Aimbiré F, Martins RA, Carvalho RA. Análise do efeito do ultra-som no edema inflamatório agudo: estudo experimental. Fisioter Mov. 2005;18(2):19-24.

24. Olsson DC, Martins VMV, Pippi NL, Mazzanti A, Tognoli GK. Ultra-som terapêutico na cicatrização tecidual. Ciênc Rural. 2008;38(4):1199-207. http://dx.doi.org/10.1590/ S0103-84782008000400051

25. Draper DO, Castel JC, Castel D. Rate of temperature increase in human muscle during $1 \mathrm{MHz}$ and 3 $\mathrm{MHz}$ continuous ultrasound. J Orthop Sports Phys Ther. 1995;22(4):142-50. PMid:8535471.

26. Van der Windt DA, Van der Heijden GJ, Van den Berg SG, Ter Riet G, De Winter AF, Bouter LM. Ultrasound therapy for musculoskeletal disorders: a systematic review. Pain. 1999;81(3):257-71. http://dx.doi.org/10.1016/ S0304-3959(99)00016-0

27. Casarotto RA, Adamowski JC, Fallopa F, Bacanelli F. Coupling agents in therapeutic ultrasound: acoustic and thermal behavior. Arch Phys Med Rehabil. 2004;Jan;85(1):162-5. http://dx.doi.org/10.1016/ S0003-9993(03)00293-4

28. Fu SC, Shum WT, Hung LK, Wong MW, Qin L, Chan KM. Low-intensity pulsed ultrasound on tendon healing: a study of the effect of treatment duration and treatment initiation. Am J Sports Med. 2008;36(9):1742-9. PMid:18645043. http://dx.doi.org/10.1177/0363546508318193

29. Speed CA. Therapeutic ultrasound in soft tissue lesions. Rheumatology. 2001;40(12):1331-6. PMid:11752501. http://dx.doi.org/10.1093/rheumatology/40.12.1331

30. Alexander LD, Gilman DR, Brown DR, Brown JL, Houghton PE. Exposure to low amounts of ultrasound energy does not improve soft tissue shoulder pathology: a systematic review. Phys Ther. 2010;90(1):14-25. PMid:19910457. http://dx.doi.org/10.2522/ptj.20080272

31. Oakley EM. Application of continuous beam ultrasound at therapeutic levels. Physiotherapy. 1978;64(6):169-72. PMid:674399.

32. Hoogland R. Terapia Ultrasónica [manual]. Enraf Nonius; 1986.

33. Aiyegbusi AI, Duru FI, Akinbo SR. The Morphology of the Healing Tendon: A Comparison of the Effects of Intrasound Therapy and Therapeutic Pulsed Ultrasound. Connect Tissue Res. 2012;53(6):478-84. PMid:22574701. http://dx.doi.org/10.3109/03008207.2012.690793

34. Ng GY.Comparing therapeutic ultrasound with microamperage stimulation therapy for improving the strength of Achilles tendon repair. Connect Tissue Res. 2011 Jun;52(3):178-82. PMid:20672987. http:// dx.doi.org/10.3109/03008207.2010.500752

35. Eckelman WC, Kilbourn MR, Joyal JL, Labiris R, Valliant JF. Justifying the number of animals for each experiment. Nucl Med Biol. 2007;34(3):229-32. PMid:17383571. http://dx.doi.org/10.1016/j.nucmedbio.2007.01.005

36. Damy SB, Camargo RS, Chammas R, Figueiredo LFPd. Aspectos fundamentais da experimentação animal - aplicações em cirurgia experimental. Rev Assoc Med Bras. 2010;56(1):103-11. PMid:20339795. http:// dx.doi.org/10.1590/S0104-42302010000100024

37. Reddy GK, Stehno-Bittel L, Enwemeka CS. Laser photostimulation accelerates wound healing in diabetic rats. Wound Repair Regen. 2001;(3):248-55. PMid:11472621. http://dx.doi.org/10.1046/j.1524-475x.2001.00248.x

38. Koeke PU, Parizotto NA, Carrinho PM, Salate AC. Comparative study of the efficacy of the topical application of hydrocortisone, therapeutic ultrasound and phonophoresis on the tissue repair process in rat tendons. Ultrasound Med Biol. 2005;31(3):345-50. PMid:15749557. http://dx.doi.org/10.1016/j.ultrasmedbio.2004.12.005

39. Carrinho PM, Renno AC, Koeke P, Salate AC, Parizotto NA, Vidal BC. Comparative study using $685-\mathrm{nm}$ and $830-\mathrm{nm}$ lasers in the tissue repair of tenotomized tendons in the mouse. Photomed Laser Surg. 2006;24(6):754-8. PMid:17199477. http://dx.doi. org/10.1089/pho.2006.24.754

40. Baldan C, Pasqual AM, Schiavinato AM, Casarotto RA. Dose-dependência do laser de baixa intensidade $(670 \mathrm{~nm})$ na viabilidade de retalhos cutâneos randômicos em ratos. J Health Sci Inst. 2010;28(4):359-62.

41. Arruda ERB, Rodrigues NC, Taciro C, Parizotto NA. Influência de diferentes comprimentos de onda da laserterapia de baixa intensidade na regeneração tendínea do rato após tenotomia. Rev Bras Fisioter. 2007;11(4):283-8. http://dx.doi.org/10.1590/S1413-35552007000400007

42. Bélanger A. Therapeutic eletrophysical agents: evidence behind practice. 2nd ed. Philadelphia. Lippincott Williams \& Wilkins; 2010.

43. Draper DO, Edvalson CG, Knight KL, Eggett D, Shurtz J. Temperature increases in the human achilles tendon during ultrasound treatments with commercial ultrasound gel and full-thickness and halfthickness gel pads. J Athl Train. 2010;45(4):333-7. PMid:20617906 PMCid:2902025. http://dx.doi. org/10.4085/1062-6050-45.4.333

44. Ng GY, Fung DT. The effect of therapeutic ultrasound intensity on the ultrastructural morphology of tendon repair. Ultrasound Med Biol. 2007;33(11):17504. PMid:17630094. http://dx.doi.org/10.1016/j. ultrasmedbio.2007.05.019

45. Silva JMN, Carvalho JP, Moura Júnior MJ, Arisawa EA, Martin AA, Sá HP, et al. Estudo da ação do ultrassom terapêutico em modelo experimental de tendinite em ratos Wistar. Cons Saúde. 2010;9(4):625-32. http://dx.doi. org/10.5585/conssaude.v9i4.2380

46. Belanger A. Therapeutic eletrophysical agents: evidence behind practice. 2nd ed. Philadelphia. Lippincott Williams \& Wilkins; 2010.

47. Culaw EM, Clark CH, Merrilees MJ. Connective tissues: matrix composition and its relevance to physical therapy. Phys Ther. 1999;79(3):308-19.

48. Aparecida de Aro A, Vidal BC, Pimentel ER. Biochemical and anisotropical properties of tendons. Micron. 2012;43(2-3):205-14. PMid:21890364. http:// dx.doi.org/10.1016/j.micron.2011.07.015 
49. Chiquet M. Regulation of extracellular matrix gene expression by mechanical stress. Matrix Biol. 1999;18(5):417-26. http://dx.doi.org/10.1016/ S0945-053X(99)00039-6

50. Soma CA, Mandelbaum BR. Repair of acute Achilles tendon ruptures. Orthop Clin North Am. 1995;26(2):239-47. PMid:7724190.

\section{Correspondence}

Thiago Saikali Farcic

Av. Yojiro Takaoka, 3500

CEP 06500-000, Santana de Parnaiba, SP, Brasil e-mail: thiago@unip.br 